\title{
Does Credit Growth 'Cause’ Current Account Deficits? Evidence from Turkey
}

\author{
Aylin Soydan \\ Faculty of Economics and Administrative Sciences, Okan University, Turkey
}

Copyright $\bigcirc 2016$ by authors, all rights reserved. Authors agree that this article remains permanently open access under the terms of the Creative Commons Attribution License 4.0 International License

\begin{abstract}
The extent of current account deficits in the Turkish economy has reached alarming levels in the past few years. Beside other arguments, one line of debate has recently been put forward by the Central Bank of the Republic of Turkey; it is stated that credit expansion in the economy has been one of the leading reasons behind the large current account deficits. When the annual credit growth reached the level over 30 per cent in 2010, concerns regarding financial and macroeconomic stability were pronounced, and some policy measures were taken by the central bank in order to bring credit growth down to more 'sustainable' levels, as stated. This study aims to empirically analyse the relationship between current account balances and domestic credit dynamics in the case of Turkey. To this end, the paper employs the ARDL bounds testing methodology and investigates causality implications between domestic credit and external balance variables. The empirical findings of the study suggest Granger causality running from domestic credit growth to external balances.
\end{abstract}

Keywords Credit Growth, Current Account Deficits, ARDL, Bounds Testing, Causality

\section{Introduction}

Large and persistent current account deficits especially in developing economies have regained attention within the academic and policy making circles over the past decade. Owing to the concerns, efforts to identify the determinants and implications of current account have been intensified, as indicated by the expansion of the related studies.

Similarly, the Turkish economy has witnessed an upward trend in current account deficits since the mid-2000s. Following the 2001 crisis, the current account deficits-to-GDP ratio started increasing; when the ratio reached the 4 per cent level in 2004, deterioration in the current account balances was fairly disturbing. The deficits continued rising, hovered around 6 per cent between 2006 and 2008, and reached the level of 10 per cent of GDP in
2011, leading to serious concerns about the sustainability of those levels.

Regarding the deterioration in current account balances of the economy, one line of debate was put forward by the Central Bank of the Republic of Turkey (CBRT), along with other arguments. It was stated that high credit growth had been one of the foremost reasons for the large current account deficits of the economy since the mid-2000s. ${ }^{1}$ When the domestic credit growth rate in Turkey reached the level over 30 per cent in 2010, concerns regarding financial and macroeconomic stability were pronounced by the authorities.

Increasing risks in the face of surging short-term capital inflows, deteriorating current account balance and unprecedented rapid credit growth called for an alternative policy approach (see e.g. [5]). Effective from November 2010, the CBRT implemented a new policy framework by utilising several complementary instruments to achieve stability with a specific emphasis on credit expansion. In this framework, the central bank planned to gradually decrease policy rates to reduce short-term capital flows and credit expansion. In order to curb credit growth, some non-interest rate measures, such as changes in reserve requirements and implementation of a maximum limit on the fraction of housing credit provided by banks, were enforced. These measures were supposed to have a contractionary impact on current account deficits. As stated by the governor of the central bank, if credit growth reaches 'unsustainable' levels, further macroprudential policy tools could be implemented in order to assure financial and macroeconomic stability.

In the economic literature there is a considerably large theoretical and empirical work on the determinants and implications of current account deficits. The subject of high and excessive credit growth has also been an issue of concern in the past couple of decades and been debated

1 Concerns have been expressed at various speeches given by the Deputy Prime Minister and by the governor(s) of the Central Bank of Turkey as well as in the reports and policy notes circulated by the central bank. See e.g. [1-4]. 
from various angles in the related literature. However, the number of studies dealing with the relationship between current account balances and domestic credit expansion seems to be very limited. In a group of studies, a credit variable appears in the models for the determinants of current account deficits [6-10]. In these models credit variable is used to represent the impact of financial factors on the current account, and the results generally suggest a deteriorating impact of credit expansion on current account balances.

This study aims to empirically analyse effects of credit expansion on the current account balances in the Turkish economy. The findings of the paper should also have implications for the economic policy debate as the recent monetary policy measures have been justified on the basis of the achievement of financial and macroeconomic stability, decline in current account deficits being one of the foremost targets.

To investigate the causality implications between domestic credit expansion and current account deficits, the study employs the autoregressive distributed lag (ARDL) bounds testing approach developed by Pesaran and Shin [11] and Pesaran et al. [12]. ${ }^{2}$ This methodology considers the possibility of a long-run relationship among the variables while also incorporating short-run dynamics into the testing procedure. Hence, as a cointegration technique, it utilises short- and long-run information in the data in an error-correction framework. ${ }^{3}$ Additionally, the ARDL bounds testing approach to long-run relationship has some advantages as discussed in Section 4.

The rest of the study is organised as follows. Next section reviews the relevant work in the literature, whereas Section 3 provides an overview of the current account balances and growth in private credits in the Turkish economy. The data and estimation procedure in the study, namely the ARDL bounds testing framework, are presented in Section 4. Section 5 reports and discusses empirical findings. Finally, Section 6 draws some conclusions.

\section{Literature Review}

In the relatively old, broad literature on the economic growth - financial development nexus, which rather focuses on a positive association despite the disagreement on the direction of causation, credit growth is thought to indicate financial development, and hence seen as a positive sign of growth and vitality in the economy.

2 Although the above-mentioned resources are widely referred in the related literature, the ARDL bounds testing approach is developed in the earlier studies of these aouthors, e.g. $[13,14]$.

3 The time series literature suggests that when the variables in the analysis are not stationary, spurious regressions are likely to arise. To avoid any information loss by differencing, it is suggested to consider the existence of long-run relationship(s) among the variables of the model. A number of techniques are available to test the presence of long-run/ cointegration relationship among the time series variables (see e.g. [15-17] for the widely-used cointegration procedures).
However, in a more recent literature, a rapid credit growth process is often considered to be a leading indicator of potential problems in the economy. An increasing number of studies argue that rapid credit growth impedes financial stability and raises the probability of a crisis (see e.g. [18-23]). The issue of credit growth has mostly been dealt with in the studies on credit booms, and it is argued that 'excessive' credit growth can indicate credit booms, paving the way for future busts. Especially, high credit growth processes in some developing and transition economies over the past decade has caught the attention in academic and policy making circles. ${ }^{4}$ The recent experience of high credit growth following the global crisis is also pointed out by international bodies like the IMF, with a concern that those countries may be experiencing a credit boom that can be followed by a bust [33].

Credit growth is perceived as a threat to macroeconomic and financial stability particularly when it reaches 'excessive' levels. ${ }^{5}$ In an economic growth phase, as financial institutions are optimistic about the ability to repay, they are very likely to lend high-risk borrowers, leading to an accumulation of potentially bad loans. Macroeconomic stability can be threatened further by rapid credit expansion as rise in private sector loans may overstimulate aggregate demand and cause the economy to overheat, with implications for inflation, interest rates, real exchange rate, and current account balances. ${ }^{6}$ Hence, current account deficits appear to be one of the possible instabilities caused by high credit expansion, while leading to serious concerns themselves.

On the other hand, a current account deficit is -by itselfnot good or bad. It can arise for various reasons and reflects underlying economic trends, which may be desirable or undesirable for a country at a particular point in time [40,41]. Distress regarding the current account deficit mainly stems from its size and persistence, and also relates to its financing methods as well as origins.

Among other factors, for example, if a current account deficit originates from or is fed by credit booms, which in turn, is derived by high level of short-term international capital flows, it is taken into account more cautiously [40-42]. In their paper on financial crises, Jorda et al. [21] underline the association between credit growth and current account balance, which has become much tighter in recent decades. The authors argue that in a globalised economy with capital mobility, credit cycles and capital flows have the potential

4 The issue of excessive credit growth has been debated for the case of emerging economies, such as central and eastern European countries (CEECs) that witnessed reasonably high credit growth rates in the $2000 \mathrm{~s}$ prior to the current global crisis, as well as some others, including Turkey, which have experienced rapid credit expansion since the eruption of crisis. For the work on the CEECs' case see e.g. [28-32].

5 Credit expansion may be driven by many factors related both the supply and demand sided of the credit market, for the debate see e.g. [26,34-37]. Some external factors, like changes in foreign capital flows, can accelerate credit growth as well; see e.g. [20,27,33,38,39].

6 For macroeconomic implications of excessive credit growth, see e.g. $[19,26,27]$. 
to reinforce each other more strongly than before. They also refer to the historical data and claim that high rates of credit growth coupling with widening current account deficits pose stability risks.

Intensive capital inflows are expected to cause a credit expansion and appreciation of the local currency, and both can deteriorate the current account balance and increase the fragility of the economy against abrupt changes in capital movements. Acceleration in credit growth increases expenditures on goods with high import component, like durable consumption goods and investments, whereas excessive appreciation in the exchange rate fuels the demand for imported goods.

More specifically, in the literature on sudden stops and current account reversals, credit growth is seen as one of the indicators of current account reversals along with large current account deficits (see e.g. [43-45]). ${ }^{7}$ For example, in his study on the Southeast Asia's experience with current account deficits, Moreno [46] underlines various significant external and internal vulnerabilities, and points to the increasing financial fragility that was indicated by various factors such as rising domestic credits-to-GDP ratio.

Despite the alleged association between current account deficits and domestic credit growth, the number of studies which directly refer to the relationship between current account deficits and credit growth seems to be very limited [6-10]. Those studies mainly employ some models to identify the determinants of current account deficits and domestic credit is included into these models as a proxy for financial variables. It is used as the growth rate or as a share of GDP to represent financial factors' impact. ${ }^{8}$ The findings of the papers generally suggest an adverse impact of domestic credit growth on current account balances.

In their study on the Greek economy, Biztis et al. [6] investigate the determinants of the current account balance for the period following the accession to the EU and EMU by employing the Johansen cointegration technique in a VECM framework. The empirical analysis suggests that the key factor for increasing current account deficits in the long run is the rise in domestic credits, which in turn, stems from financial liberalisation and low interest rates.

Brissimis et al. [7] attempt to identify the determinants of the current account balance in Greece for the period between 1960 and 2007 by using the cointegration methodology and two non-linear models. Their analysis aims at revealing the main macroeconomic, financial and structural factors affecting net national saving, and hence, shaping the current account developments. The findings of the empirical analysis suggest that the financial liberalisation and later

7 It is generally argued that probability of a reversal is higher for countries with a large current account deficit, high external debt ratio, rapid growth of domestic credit, lower initial GDP, and a high appearance of sudden stops in their region.

8 In the related literature, although factors like fiscal positions, economic growth, demographic factors, net foreign asset positions, level of oil dependency are identified as the main determinants of the current account balance, a lesser attention has been given to the financial variables. monetary integration processes resulted in considerable private credit expansion and decline in private savings, contributing to an extensive deterioration of the current account deficits. Credit growth and current account deficits were maintained at high levels during the euro area membership, but slowed down with the impact of the 2007/08 global crisis.

Atoyan et al. [8], IMF [9] and Ekinci et al. [10] employ panel regression techniques for various groups of countries to investigate the impact of domestic credit growth on current account balances. The credit variable is used as the growth rate or as a share of GDP in those models for the current account to represent financial expansion. ${ }^{9}$ The overall results from these studies indicate a significant impact of domestic credit growth on the current account balances.

Beside the above mentioned studies based on the models for the current account balances, Telatar [47] looks at the causality between private credits and external balance in his study on the Turkish economy. The author investigates Granger causality implications in a standard VAR framework for the period 2003Q1-2010Q4, and finds no causality from total credits towards current account deficits, whereas the empirical results suggest causality running from consumer credits towards current account deficits.

This study attempts to empirically investigate the causal inferences between credits to the private sector and current account balances in the Turkish economy for a longer time period in a cointegration framework. To this end the paper employs the ARDL bounds testing methodology, which considers both the long- and short-run dynamics in the data and allows for different degrees of integration of the variables in the analysis.

\section{Current Account Deficits and Credit Expansion in Turkey}

The Turkish economy did not run very large current account deficits until the mid-2000s as can be seen in Fig.1. However, a rising trend of the deficits can clearly be seen in the early 2000s when the economy began to grow rapidly following the severe crisis of 2001. The deficits-to-GDP ratio hovered around 6 per cent from 2006 to 2008, and then reflecting the impact of the global crisis on the economy, the current account deficits narrowed sharply in line with the slowdown in the economic activity in 2009.

In 2010 when the economy returned to the path of rapid economic growth, the current account deficit broadened again compared to its pre-crisis levels. The deterioration in the current account intensified further in 2011, reaching the

9 For example IMF [9] explains the underlying mechanism of the influence of financial excess on the current account balance as follows: If the authorities fail to implement policies to reduce financial excess, a demand boom might occur, which causes a weaker current account balance. 
9.6 per cent level, followed by a partial recovery in 2012 . After this recovery the ratio increased again to the level of 7.9 per cent. The extent of current account deficits maintains as one of the critical problems of the Turkish economy with a rate around 5 per cent.

Capital inflows have placed a significant role in financing current account deficits in the Turkish economy in the past couple of decades, while supporting economic growth despite the implications for macroeconomic instability due to short-term and volatile characteristics. As current account deficits have been financed almost completely through short-term capital inflows, the economy has witnessed a number of crises accompanied by sudden stops during the same period.
The domestic private credit has been fed by capital inflows and its level relative to GDP has displayed a rapid increase in the last ten years (Fig. 2). The ratio stayed at relatively low levels, around $13-14$ per cent on average, between 1987 and 2002. After hitting its minimum in 2002, the level of credits as percentage of income continued climbing, exceeded the 50 per cent level at the end of 2012, approaching the level of 65 per cent in the second half of 2014.

Fig.3 represents annual real growth rates of GDP and credits. While the economic growth dynamics of the Turkish economy has an unstable and volatile character, the credit growth process exhibits even larger fluctuations, which can be seen in the figure.

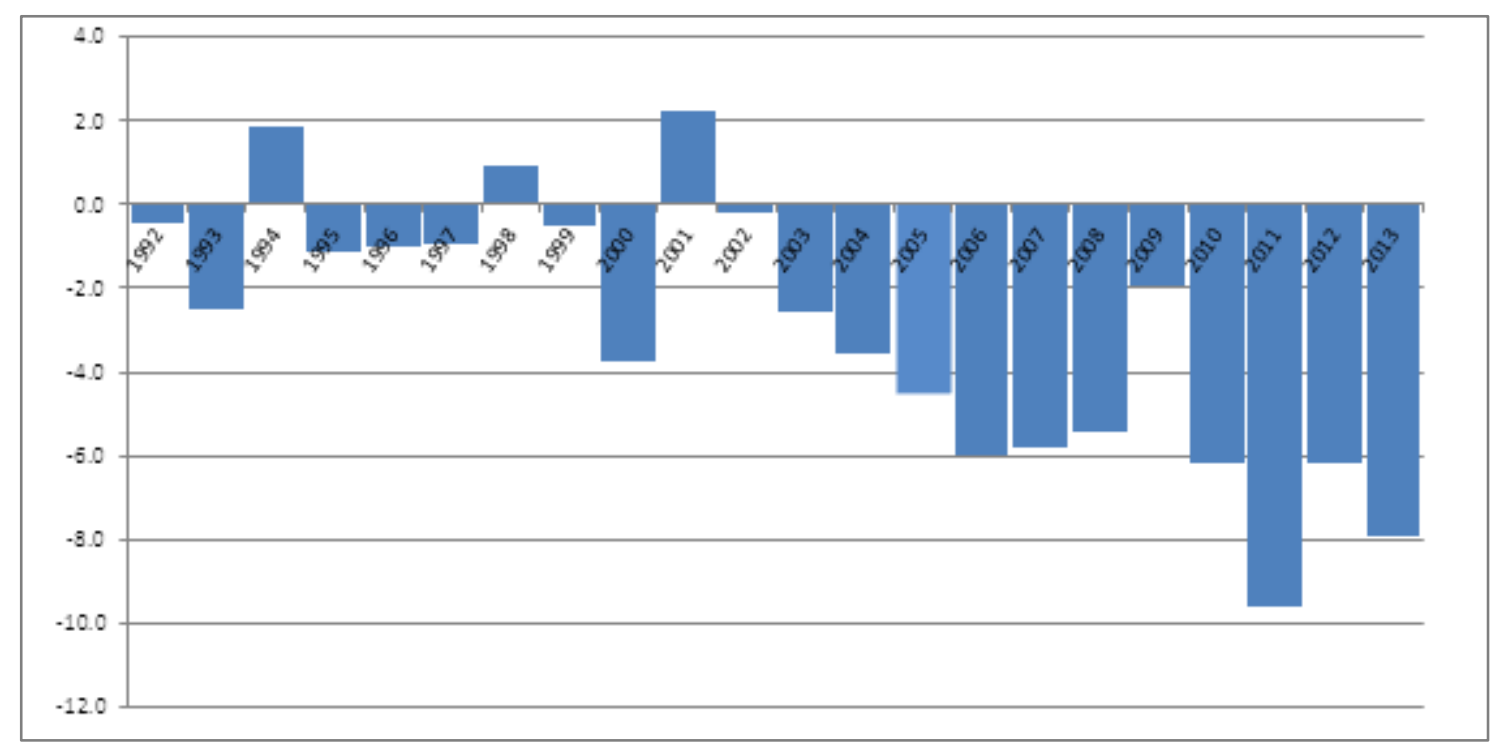

Source: Central Bank of Republic of Turkey (CBRT) database

Figure 1. Current Account Balance / GDP (\%)

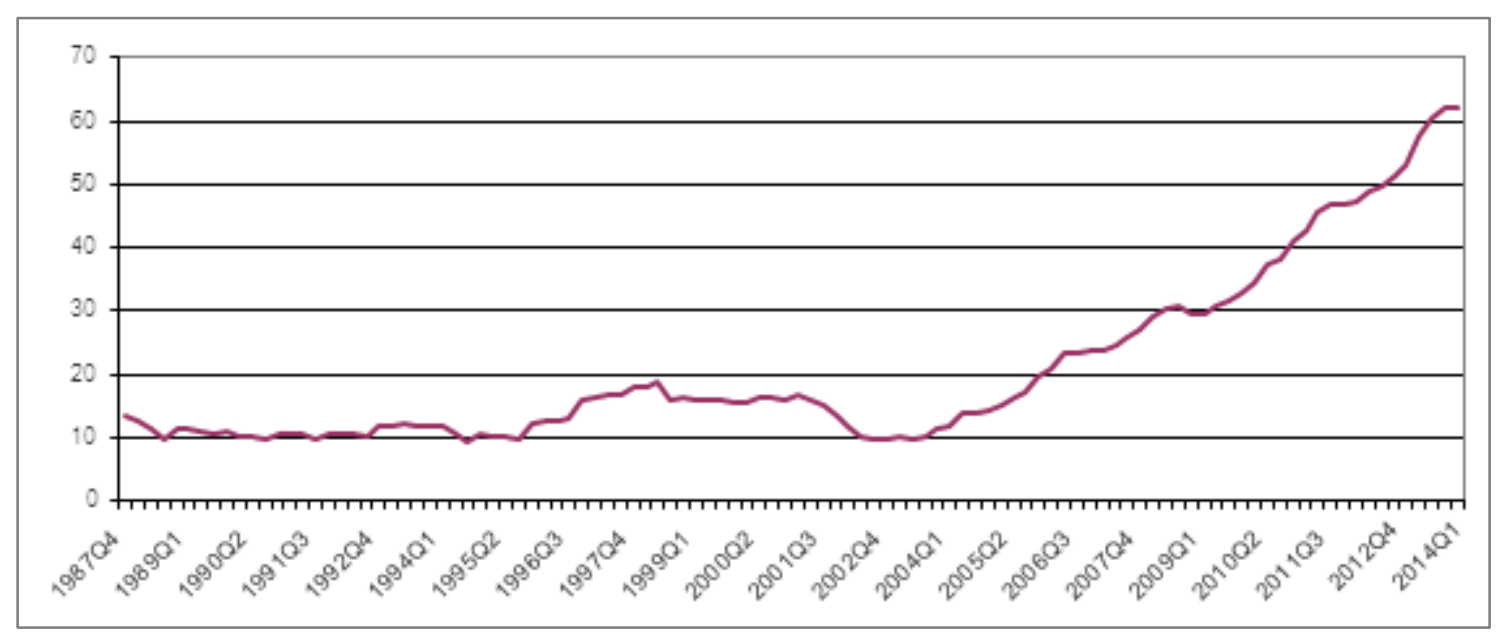

Source: CBRT database

Figure 2. Credit / GDP (\%) 


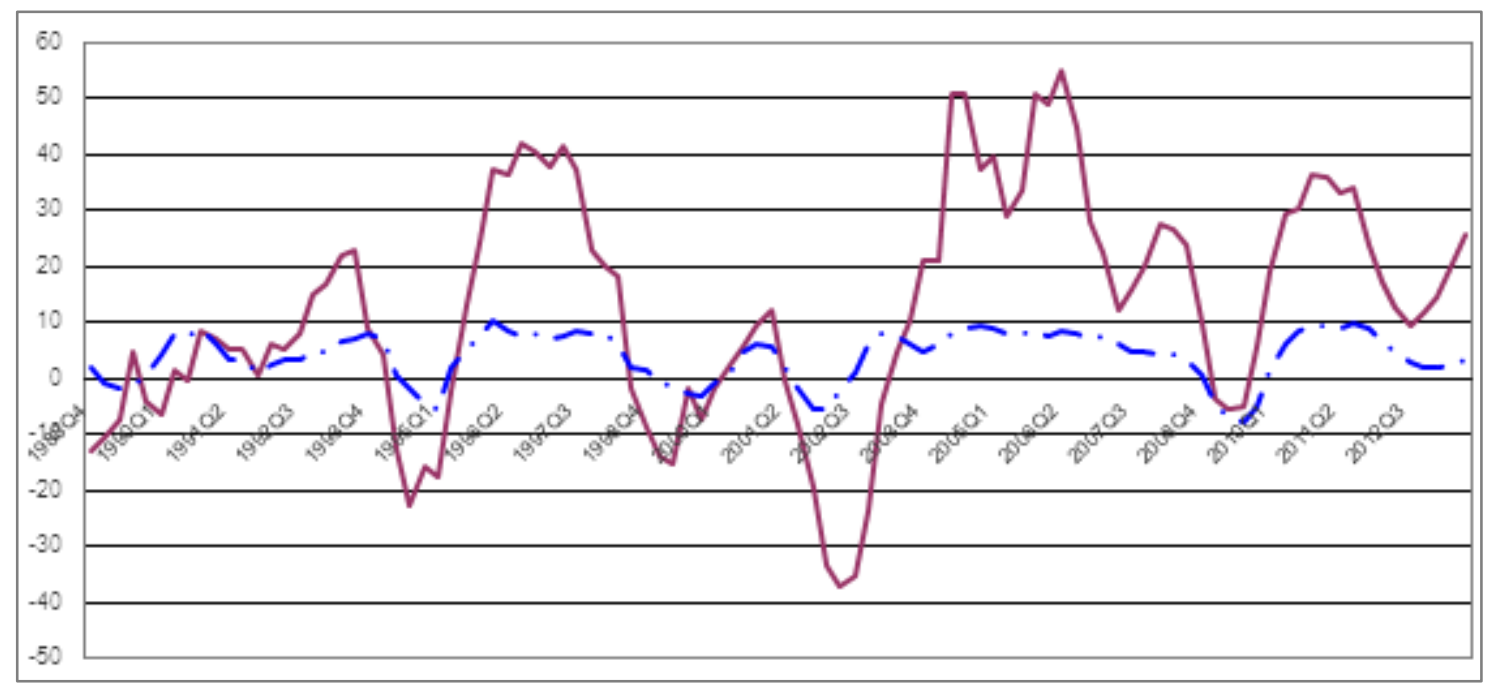

Source: CBRT database

Figure 3. Economic Growth (\%) and Credit Growth (\%)

There have been various factors feeding into the credit expansion, such as low global interest rates, increased supply of credit backed with the strong balance sheets of the domestic banking sector, as well as growth in output $[4,48]$. The Turkish economy experienced a rapid recovery following the contraction in 2009. After the first phase of the global crisis, international financial capital found its way into emerging economies in search of higher returns. The Turkish economy has been one of those, and capital flows have fed into credit expansion over the past few years.

It is argued that these inflows have sustained a credit boom in Turkey, which in turn, has had an impact on imports; hence, widened the current account deficits further threatening the stability of the economy. ${ }^{10}$ Trade deficits have been the driving force for current account deterioration in Turkey. The rapid expansion in credits reinforced the growth in domestic demand, and together with the strong Turkish lira, resulted in higher demand for imports. On the other hand, exports remained depressed due to weak external demand and appreciated domestic currency. As a result, foreign trade and current account balances registered a notable deterioration, which raised the vulnerability of the economy against sudden reversals in the global risk appetite.

When credit growth reached alarming levels along with large current account deficits, the concerns regarding financial and macroeconomic stability were pronounced by the authorities. In order to curb the build-up of macroeconomic and financial imbalances, more specifically current account deficits, the central bank designed and implemented a new policy framework by exploiting various instruments with an explicit emphasis on credit growth as mentioned earlier.

10 In the World Economic Outlook by the IMF [33] Turkey is regarded as one of the leading countries (even the first) that have been experiencing a noticeable rise in real credit growth, with a concern that such expansions are close to those experienced before previous credit booms and busts.

\section{Estimation Methodology and Data}

\subsection{ARDL Bounds Testing Approach}

This study employs the ARDL bounds testing approach to investigate causality implications between credit growth and current account deficits in the Turkish economy. This approach involves an error-correction framework which incorporates the short- and long-run information in the data as being a cointegration technique. On the other hand, it has certain advantages in comparison with the conventional cointegration techniques. First of all, the ARDL methodology avoids classification of the variables into $I(1)$ or $I(0)$ and does not require the variables to have the same order of integration. As pointed by Pesaran and Shin [11] and Pesaran et al. [12], the ARDL bounds testing approach can be implemented irrespective of whether the variables are purely $I(0)$, purely $I(1)$, or mutually cointegrated. The error-correction model, which integrates short-run dynamics to the long-run equilibrium, can be derived through a simple linear transformation of the underlying ARDL model. The long- and short-run parameters of the model in question are estimated simultaneously. The ARDL model takes sufficient numbers of lags to capture the data generating process and uses a dynamic framework of a general-to-specific modelling [49]. Finally, the small sample properties of the ARDL approach are superior to standard cointegration techniques [11,49].

The first stage in the ARDL methodology is to test for the existence of a long-run/ level relationship between the variables of interest by employing the bounds testing procedure [11,12]. The bounds testing procedure requires estimating a model in the form of an unrestricted error-correction model (UECM) for the relevant variable(s). 
The UECM for current account deficits in our case can be written as ${ }^{11}$

$$
\begin{gathered}
\Delta C A D_{t}=\alpha_{0}+ \\
\alpha_{1} t+\sum_{j=1}^{s} \beta_{1 j} \Delta C A D_{t-j}+\sum_{j=0}^{s} \beta_{2 j} \Delta C R E D I T_{t-j} \\
+\pi_{1} C A D_{t-1}+\pi_{2} C R E D I T_{t-1}+e_{t}
\end{gathered}
$$

where $\Delta$ is the first difference operator and $s$ is the lag order selected by an information criterion, such as AIC (Akaike Information Criterion) or SBC (Schwarz's Bayesian Criterion). $t$ denotes the linear time trend, and $e_{t}$ represents the residual of the equation. The linear combination of the lagged levels of the variables corresponds to the long-run relationship with parameters of $\pi_{\mathrm{i}} \mathrm{s}$, i.e. replaces the lagged error-term of a standard error-correction representation. Therefore, as suggested in the related studies, to determine whether a long-run relationship exists between the variables, the bounds testing procedure involves $F$-testing, i.e. testing the joint significance of the lagged level variables with the null hypothesis of no long-run relationship, $\mathrm{H}_{0}: \pi_{1}=\pi_{2}=$ 0 .

On the other hand, as the computed $F$-statistics do not have a standard distribution, two sets of asymptotic critical values tabulated in Pesaran et al. [12] are used in the anlaysis. ${ }^{12}$ As those critical values provide bounds for all possibilities for the order of integration of the variables, it is called a bounds testing procedure. In this setting, the upper bound values assume all variables are purely $I(1)$ and the lower bound values assume that they are purely $I(0)$. Hence, if the calculated $F$-statistic lies above the upper level of the band, the null hypothesis of no long-run relationship can be rejected irrespective of whether the order of integration of the variables are $I(0)$ or $I(1)$. Similarly, if the $F$-statistic falls below the lower level of the band, the null of $\mathrm{H}_{0}$ cannot be rejected, indicating lack of a long-run relationship. The statistics between the upper and lower critical values imply an inconclusive inference.

Having identified the existence of long-run relationship among variables by employing the bounds testing procedure, the analysis continues with the error-correction representation of the ARDL model. First, with the lagged levels of the variables, the underlying $\operatorname{ARDL}(\mathrm{p}, \mathrm{q})$ model for the analysis can be written as

$C A D_{t}=\gamma_{0}+\gamma_{1} t+\sum_{j=1}^{p} \delta_{1 j} C A D_{t-j}+\sum_{j=0}^{q} \delta_{2 j} C R E D I T_{t-j}+\varepsilon_{t}$

The appropriate lag lengths $p$ and $q$ are determined by an information criterion. Given the underlying ARDL equation, the error-correction model (ECM) representation of the ARDL model is:

11 This equation is estimated with and without a linear trend. Our results below are also given with a linear trend when appropriate.

12 Narayan [49] developed the set of critical values for sample size ranging from 30 to 80 .

$$
\begin{gathered}
\Delta C A D_{t}=\varphi_{0}+\varphi_{1} t+\sum_{j=1}^{p-1} \sigma_{1 j} \Delta C A D_{t-j}+ \\
+\sum_{j=0}^{q-1} \sigma_{2 j} \Delta C R E D I T_{t-j}+\lambda \cdot E C T_{t-1}+\mu_{t}
\end{gathered}
$$

where $\mu_{t}$ represents the residual of the equation. The lagged differences of the variables denote the short-run dynamics with the parameters $\sigma_{i} \mathrm{~s} . E C T_{\mathrm{t}-1}$ is the lagged error-correction term obtained from the long-run relationship. The coefficient of the error-correction term $\lambda$ shows how fast deviations from the long-run equilibrium are eliminated, and should have a negative sign.

It is important to note that the existence of a long-run relationship among variables does not necessarily imply stability of the parameters. Due to structural changes in the economies it is likely that macroeconomic series may be subjected to structural break(s). To this end, the stability of the short- and long-run coefficients are checked through the cumulative sum (CUSUM) and cumulative sum of squares (CUSUMSQ) tests proposed by Brown et al. [50]. The CUSUM and CUSUMQ statistics are updated recursively and plotted against the break points of the model. These tests are quite general for structural change in that they do not require a prior determination of where the structural break(s) takes place, and usually implemented by means of graphical representation. Providing that the plot of these statistics fall inside the critical bounds of 5 per cent significance, the coefficients of a given regression are stable.

Finally, to investigate the Granger causality implications, the ECM version of the ARDL model given by (3) is used. ${ }^{13}$ The short-run or weak Granger causality from the credit variable to current account deficits is detected by testing $\mathrm{H}_{0}$ : $\sigma_{2 j}=0$ for all $j \mathrm{~s}$ in the equation. Another source of causality, i.e. the long-run causality, is investigated through the error-correction term of the model, by testing $\mathrm{H}_{0}: \lambda=0$. The strong Granger causality is detected by testing $\mathrm{H}_{0}$. $\sigma_{2 j}=\mu=0$ for all $j \mathrm{~s}$ in the equation. In each case, rejecting the null hypothesis indicates that the selected credit variable does not Granger-cause the related external deficit variable.

\subsection{Data}

In order to investigate the relationship between current account balances and domestic private credit expansion, the ARDL bounds testing approach is employed for the following variables:

cad : current account deficit (percentage of GDP)

trade : trade deficit (percentage of GDP)

credit : total private credit use (percentage of GDP)

hhold : credit use of households (percentage of GDP)

13 In the literature Granger-causality has been one of the widely used empirical concepts. A general definition for the Granger causality can be given as follows: Since the future cannot predict the past, if variable $x$ Granger causes variable $y$, then the changes in $\mathrm{x}$ should precede changes in $y$. Therefore, in a regression of $y$ on other variables (including its own past values), if we include past or lagged values of $x$ and it significantly improves the prediction of $y$, then we can say that $x$ Granger causes $y$. A similar definition applies if y Granger causes $x$. 
The trade balance is used as an alternative to the current account balance since trade deficits appears to be the driving force for current account deficits of the Turkish economy. The credit use of household sector is also chosen to substitute the total private credit use as the use of consumer credits towards imported goods is claimed to be one of the main factors behind trade deficits.

In the analysis annualised data are used for the period of analysis is 1992Q1-2014Q1. The series are provided from the CBRT website. cad and trade variables are used after adjusted by (-1).

\section{Empirical Results and Discussion}

Although the ARDL methodology does not require the variables to have the same order of integration, prior to the analysis time series properties of the relevant series need to be investigated. It is necessary to confirm that all the variables satisfy the underlying assumptions of the ARDL bounds testing approach, i.e. no variable is $I(2)$ as the critical bounds provided by Pesaran et al. (2001) [12] are not valid if the order of integration of any of the variables is greater than one.

Before proceeding to the estimation stage, unit root tests with and without structural breaks are undertaken. For the first group, the augmented Dickey and Fuller [51] (ADF), Phillips and Perron [52] (PP), Elliott et al. [53] (Dickey-Fuller GLS / DF-GLS), and Kwiatkowski et al. [54] (Kwiatkowski, Phillips, Schmidt and Shin - KPSS) unit root tests are employed. The results are reported in Table 1.

The null hypothesis for testing for unit roots is mostly expressed as the presence of a unit root, i.e. non-stationarity of the series. However, Kwiatowski et al. [54] suggest testing the null hypothesis of stationarity against the alternative of a unit root. Therefore, for most of the unit root tests above, rejection of the null hypothesis implies stationarity of the series, while a significant KPSS statistic means rejection of stationarity. As reported in Table 1, for most cases variables seem to be integrated of order one, $I(1)$ processes, whereas unit root tests for current account deficits do not provide conclusive results.

Table 1. Unit Root Tests without Structural Breaks

\begin{tabular}{|c|c|c|c|c|c|}
\hline & & ADF & DF-GLS & PP & KPSS \\
\hline \multicolumn{6}{|l|}{ Levels } \\
\hline \multirow[t]{4}{*}{ Intercept } & $c a d$ & $-2.84[1]^{*}$ & $-2.45[1]^{* * *}$ & -1.67 & $1.05^{* * *}$ \\
\hline & trade & $-1.91[5]$ & $-1.93[5]^{*}$ & -2.13 & $0.78 * * *$ \\
\hline & credit & $2.62[1]$ & $2.76[1]$ & 3.75 & $0.95^{* * *}$ \\
\hline & hhold & $1.58[3]$ & $-1.02[4]$ & 2.24 & $1.09 * * *$ \\
\hline \multirow[t]{4}{*}{ Intercept and trend } & $c a d$ & $-5.31[1]^{* * *}$ & $-5.12[1]^{* * *}$ & -3.09 & $0.13^{*}$ \\
\hline & trade & $-2.95[5]$ & $-2.60[5]$ & $-3.20 *$ & $0.12 *$ \\
\hline & credit & $0.45[1]$ & $-0.67[2]$ & 0.85 & $0.28 * * *$ \\
\hline & hhold & $-1.06[3]$ & $-0.96[4]$ & -0.95 & $0.30 * * *$ \\
\hline \multicolumn{6}{|l|}{ First Differences } \\
\hline \multirow[t]{4}{*}{ Intercept } & cad & $-6.33[3] * * *$ & $-6.36[3] * * *$ & $-4.32 * * *$ & 0.03 \\
\hline & trade & $-4.35[4] * * *$ & $-1.27[4] * * *$ & $-4.74 * * *$ & 0.05 \\
\hline & credit & $-3.70[1] * * *$ & $-3.47[1] * * *$ & $-5.47 * * *$ & $0.79 * * *$ \\
\hline & hhold & $-4.73[2] * * *$ & $-2.82[3] * * *$ & $-4.85 * * *$ & $0.68 * *$ \\
\hline \multirow[t]{4}{*}{ Intercept and trend } & cad & $-6.32[3] * * *$ & $-6.32[3] * * *$ & $-4.29 * *$ & 0.03 \\
\hline & trade & $-4.26[3] * * *$ & $-2.25[4]$ & $-4.67 * * *$ & 0.02 \\
\hline & credit & $-6.62[0] * * *$ & $-6.52[0] * * *$ & $-6.6^{* * *}$ & $0.15^{* *}$ \\
\hline & hhold & $-5.35[2] * * *$ & $-4.95[2] * * *$ & $-4.78 * * *$ & 0.08 \\
\hline
\end{tabular}

The statistics are t-ratios, except for the case of the KPSS, which uses LM statistics. The optimal lag for the ADF test is selected by the Schwarz's Information Criterion, the bandwiths for the PP and KPSS are selected by Newey-West using Bartlett kernel. $* * *, * *$ and $*$ denote significance at $1 \%, 5 \%$ and $10 \%$ levels respectively. 
The unit root tests above do not consider any possible structural break(s) in the data. However, macroeconomic series are likely to be subject to structural changes, and those changes may have implications for the stationarity analysis. Therefore, to investigate possible structural break(s) in the data, a recently developed unit root test, the Carrion-i-Silvestre et al. (2009) (CS) [56] test is also applied. The CS test, which is a GLS-based procedure comprising five test statistics, is employed due to a number of advantages. The procedure determines the breaks endogenously, and is able to identify up to five structural breaks, which can affect either the intercept and/or the slope. The CS test allows for a break under both the null and the alternative hypotheses, and in case of a break this information is used to improve power of the test.

Table 2 reports the results for the Carrion-i-Silvestre et al. (2009) test with multiple structural breaks. When the calculated statistics is smaller than the critical value, the null hypothesis is rejected. According to the test results under two options, the null of unit root is rejected for most of the variables as the statistics are smaller than the critical values. The null cannot be rejected for only two cases; for the hhold variable in the first option, and for the credit variable in the second option. Those two variables seem to be $I(1)$ processes as their first differences are stationary.

Following the unit root tests, the $F$-test is employed in the unrestricted error-correction model(s) given by (1) to test for the existence of a level relationship between the variables. The null hypothesis of no long-run relationship is tested for $\mathrm{H}_{0}: \pi_{1}=\pi_{2}=0$. The $F$-statistics for the bounds tests with and without time trend are given in Table 3.

In all cases, the calculated $F$-statistics are greater than the 1 per cent upper bound critical values provided by Pesaran $e t$ al. [12] Therefore, the null hypothesis can be rejected, implying the existence of a long-run relationship between current account deficits and total private sector credits, and in a similar vein, between trade deficits and household credits. Hence, credits and household credits can be treated as the long-run forcing variables for current account deficits and trade deficits respectively.

Table 2. Unit Root Tests with Structural Breaks: Carrion-i-Silvestre et al. (2009) Test

\begin{tabular}{|c|c|c|c|c|c|c|}
\hline & \multicolumn{5}{|c|}{ Levels } & \multirow{2}{*}{ Break Dates } \\
\hline & $\mathbf{P}_{\mathrm{T}}$ & $\mathbf{M P}_{\mathbf{T}}$ & $\mathbf{M Z}_{\mathrm{a}}$ & MSB & $\mathbf{M Z}_{\mathrm{T}}$ & \\
\hline \multicolumn{7}{|c|}{ Breaks in level and slope of time trend } \\
\hline cad & $\begin{array}{c}2.7436 \\
{[5.5719]^{*}}\end{array}$ & $\begin{array}{c}2.6914 \\
{[5.5719]^{*}}\end{array}$ & $\begin{array}{c}-60.8237 \\
{[-29.0274]^{*}}\end{array}$ & $\begin{array}{c}0.0906 \\
{[0.1342]^{*}}\end{array}$ & $\begin{array}{c}-5.5130 \\
{[-3.7785]^{*}}\end{array}$ & $\begin{array}{c}\text { 2001Q1, 2001Q4 } \\
\text { 2003Q2 }\end{array}$ \\
\hline trade & $\begin{array}{c}4.8182 \\
{[5.6625]^{*}}\end{array}$ & $\begin{array}{c}4.7649 \\
{[5.6625]^{*}}\end{array}$ & $\begin{array}{c}-35.1883 \\
{[-29.1449]^{*}}\end{array}$ & $\begin{array}{c}0.1189 \\
{[0.1337]^{*}}\end{array}$ & $\begin{array}{c}-4.1851 \\
{[-3.7801]^{*}}\end{array}$ & $\begin{array}{c}\text { 1999Q4, 2000Q4 } \\
\text { 2001Q4 }\end{array}$ \\
\hline credit & $\begin{array}{c}0.4738 \\
{[5.7305]^{*}}\end{array}$ & $\begin{array}{c}0.4629 \\
{[5.7305]^{*}}\end{array}$ & $\begin{array}{c}-400.0955 \\
{[-31.1843]^{*}}\end{array}$ & $\begin{array}{c}0.0354 \\
{[0.1294]^{*}}\end{array}$ & $\begin{array}{c}-14.1438 \\
{[-3.9378]^{*}}\end{array}$ & $\begin{array}{c}\text { 2001Q1, 2002Q4 } \\
\text { 2009Q4 }\end{array}$ \\
\hline hhold & $\begin{array}{c}6.6576 \\
{[5.3159]}\end{array}$ & $\begin{array}{c}6.6821 \\
{[5.3159]}\end{array}$ & $\begin{array}{c}-25.6413 \\
{[-29.2835]}\end{array}$ & $\begin{array}{c}0.1369 \\
{[0.1346]}\end{array}$ & $\begin{array}{c}-3.5105 \\
{[-3.7890]}\end{array}$ & $\begin{array}{c}\text { 1999Q2, 2000Q3 } \\
\text { 2002Q4 }\end{array}$ \\
\hline$\Delta$ hhold & $\begin{array}{c}1.8723 \\
{[5.0073]^{*}}\end{array}$ & $\begin{array}{c}1.8482 \\
{[5.0073]^{*}}\end{array}$ & $\begin{array}{c}-55.1940 \\
{[-17.8929]^{*}}\end{array}$ & $\begin{array}{c}0.0951 \\
{[0.1653]^{*}}\end{array}$ & $\begin{array}{c}-5.2472 \\
{[-3.0572]^{*}}\end{array}$ & $\begin{array}{c}\text { 1993Q2, 1993Q4 } \\
\text { 2013Q1 }\end{array}$ \\
\hline \multicolumn{7}{|c|}{ Breaks in slope of time trend } \\
\hline cad & $\begin{array}{c}4.1876 \\
{[7.5628]^{*}}\end{array}$ & $\begin{array}{c}4.0872 \\
{[7.5628]^{*}}\end{array}$ & $\begin{array}{c}-63.2305 \\
{[-34.7424]^{*}}\end{array}$ & $\begin{array}{c}0.0889 \\
{[0.1192]^{*}}\end{array}$ & $\begin{array}{c}-5.6190 \\
{[-4.1413]^{*}}\end{array}$ & $\begin{array}{c}\text { 1994Q4, 1999Q3 } \\
\text { 2002Q3 }\end{array}$ \\
\hline trade & $\begin{array}{c}3.0549 \\
{[7.4301]^{*}}\end{array}$ & $\begin{array}{c}2.8092 \\
{[7.4308]^{*}}\end{array}$ & $\begin{array}{c}-86.5371 \\
{[-32.3526]^{*}}\end{array}$ & $\begin{array}{c}0.0760 \\
{[0.1242]^{*}}\end{array}$ & $\begin{array}{c}-6.5760 \\
{[-4.0174]^{*}}\end{array}$ & $\begin{array}{c}\text { 2001Q1, 2008Q3 } \\
\text { 2011Q4 }\end{array}$ \\
\hline credit & $\begin{array}{c}30.2981 \\
{[8.2138]}\end{array}$ & $\begin{array}{l}27.2896 \\
{[8.2138]}\end{array}$ & $\begin{array}{c}-10.8275 \\
{[-35.9641]}\end{array}$ & $\begin{array}{c}0.2145 \\
{[0.1174]}\end{array}$ & $\begin{array}{c}-2.3223 \\
{[-4.2237]}\end{array}$ & $\begin{array}{c}\text { 1998Q2, 2001Q4 } \\
\text { 2008Q3 }\end{array}$ \\
\hline hhold & $\begin{array}{c}2.0421 \\
{[7.9898]^{*}}\end{array}$ & $\begin{array}{c}1.9629 \\
{[7.9898]^{*}}\end{array}$ & $\begin{array}{l}-141.3235 \\
{[-34.1608]^{*}}\end{array}$ & $\begin{array}{c}0.0594 \\
{[0.1200]^{*}}\end{array}$ & $\begin{array}{c}-8.3939 \\
{[-4.1104]^{*}}\end{array}$ & $\begin{array}{c}\text { 2000Q4, 2003Q1 } \\
\text { 2006Q2 }\end{array}$ \\
\hline$\Delta$ credit & $\begin{array}{c}3.1380 \\
{[7.6972]^{*}}\end{array}$ & $\begin{array}{c}3.0801 \\
{[7.6972]^{*}}\end{array}$ & $\begin{array}{c}-99.5310 \\
{[-35.7669]^{*}}\end{array}$ & $\begin{array}{c}0.0703 \\
{[0.1178]^{*}}\end{array}$ & $\begin{array}{c}-7.0002 \\
{[-4.2158]^{*}}\end{array}$ & $\begin{array}{c}\text { 1995Q2, 2001Q4 } \\
\text { 2006Q1 }\end{array}$ \\
\hline
\end{tabular}

Values in brackets are critical values obtained by the bootstrap procedure. $*$ denotes stationarity at $5 \%$ significance level (where applicable). Break dates are identified by the testing procedure and reported for original series at levels. Maximum lag length is 4.

Table 3. Bounds Tests Results and Critical Values

\begin{tabular}{|c|c|c|c|c|}
\hline & \multicolumn{4}{|c|}{$F$-Statistics } \\
\hline & \multicolumn{2}{|c|}{ Constant } & \multicolumn{2}{|c|}{ Constant and Trend } \\
\hline $\begin{array}{c}\text { Model I } \\
\text { F (cad/credit) }\end{array}$ & \multicolumn{2}{|c|}{14.6615} & \multicolumn{2}{|c|}{20.0784} \\
\hline $\begin{array}{c}\text { Model II } \\
\text { F (tradelhhold) }\end{array}$ & \multicolumn{2}{|c|}{25.7179} & \multicolumn{2}{|c|}{24.4609} \\
\hline Critical values & $I(0)$ & $I(1)$ & $I(0)$ & $I(1)$ \\
\hline $1 \%$ & 6.84 & 7.84 & 8.74 & 9.63 \\
\hline $5 \%$ & 4.94 & 5.73 & 6.56 & 7.30 \\
\hline $10 \%$ & 4.04 & 4.78 & 5.59 & 6.26 \\
\hline
\end{tabular}

Critical $F$-values for $k=1$ are provided from the relevant tables in Pesaran et al. [12]. 
Table 4. Long-Run Coefficients of the Level Relationships

\begin{tabular}{|c|c|c|c|c|}
\hline & \multicolumn{2}{|c|}{ Constant } & \multicolumn{2}{|c|}{ Constant and Trend } \\
\hline & Coefficient & $t$-statistic & Coefficient & $t$-statistic \\
\hline $\begin{array}{c}\text { Model I } \\
\text { Dependent variable : } C A D\end{array}$ & \multicolumn{2}{|c|}{$\operatorname{ARDL}(2,1)$} & \multicolumn{2}{|c|}{$\operatorname{ARDL}(2,1)$} \\
\hline credit & 0.10061 & $3.1637[0.002]^{* * *}$ & 0.0152 & $0.3871[0.700]$ \\
\hline$C$ & -0.1178 & $-0.1641[0.870]$ & -1.4425 & $-2.2324[0.028]^{* *}$ \\
\hline trend & -- & -- & 0.0719 & $3.2756[0.002]^{* * *}$ \\
\hline $\begin{array}{c}\text { Model II } \\
\text { Dependent variable : TRADE }\end{array}$ & \multicolumn{2}{|c|}{$\operatorname{ARDL}(2,1)$} & \multicolumn{2}{|c|}{$\operatorname{ARDL}(2,1)$} \\
\hline hhold & 0.2010 & $5.6108[0.000]^{* * *}$ & 0.2794 & $3.1973[0.002]^{* * *}$ \\
\hline$C$ & 3.7323 & $11.6257[0.000]^{* * *}$ & 4.2879 & $6.5858[0.000]^{* * *}$ \\
\hline trend & -- & -- & -0.0226 & $-0.9614[0.339]$ \\
\hline
\end{tabular}

$* * *, * *$ and $*$ denote significance at $1 \%, 5 \%$ and $10 \%$ levels respectively. Numbers in parenthesis are $p$-values.

Table 5. Error Correction Representations of ARDL Models

\begin{tabular}{|c|c|c|c|c|}
\hline & \multicolumn{2}{|c|}{ Constant } & \multicolumn{2}{|c|}{ Constant and Trend } \\
\hline & Coefficient & $t$-statistic & Coefficient & $t$-statistic \\
\hline $\begin{array}{c}\text { Model I } \\
\text { Dependent } \quad \text { variable }: \triangle C A D\end{array}$ & \multicolumn{2}{|c|}{$\operatorname{ARDL}(2,1)$} & \multicolumn{2}{|c|}{$\operatorname{ARDL}(2,1)$} \\
\hline$\Delta C A D_{t-1}$ & 0.68679 & $9.4565[0.000] * * *$ & 0.69960 & $10.1180[0.000] * * *$ \\
\hline Acredit & 0.22851 & $4.2143[0.000] * * *$ & 0.20182 & $4.2143[0.000] * * *$ \\
\hline trend & -- & -- & 0.01394 & $3.0608[0.003] * * *$ \\
\hline $\mathrm{ECT}_{\mathrm{t}-1}$ & -0.15645 & $-4.9673[0.000] * * *$ & -0.19402 & $-5.9975[0.000] * * *$ \\
\hline$\overline{\mathrm{R}}^{2}$ & 0.6071 & & 0.64513 & \\
\hline F-statistic & $43.5610[0.000]$ & & $38.5180[0.000]$ & \\
\hline DW-statistic & 2.0258 & & 2.1960 & \\
\hline RSS & 20.3297 & & 18.1245 & \\
\hline $\begin{array}{c}\text { Model II } \\
\text { Dependent variable }: \Delta T R A\end{array}$ & \multicolumn{2}{|c|}{$\operatorname{ARDL}(2,1)$} & \multicolumn{2}{|c|}{$\operatorname{ARDL}(2,1)$} \\
\hline$\Delta T R A_{t-1}$ & 0.73321 & $12.7034[0.000] * * *$ & 0.73180 & $12.6661[0.000] * * *$ \\
\hline shold & 0.60260 & $5.4001[0.000] * * *$ & 0.11413 & $5.4753[0.000] * * *$ \\
\hline trend & -- & -- & -0.00453 & $-0.9453[0.000] * * *$ \\
\hline $\mathrm{ECT}_{\mathrm{t}-1}$ & -0.19529 & $-6.8454[0.000] * * *$ & -0.20052 & $-6.8957[0.000] * * *$ \\
\hline$\overline{\mathrm{R}}^{2}$ & 0.77288 & & 0.7609 & \\
\hline F-statistic & $88.4768[0.000]$ & & 66.4904 & \\
\hline DW-statistic & 2.0743 & & 2.0866 & \\
\hline RSS & 10.8427 & & 10.7183 & \\
\hline
\end{tabular}

$* * *, * *$ and $*$ denote significance at $1 \%, 5 \%$ and $10 \%$ levels respectively. Numbers in parenthesis are $p$-values.

Having confirmed the existence of the long-run relationship between the variables we can now proceed to estimate the ECM version of the ARDL model. In order to determine the optimal lag lengths in the underlying ARDL model given in (2) we use SBC. For current account deficits and credit variables, and similarly, for trade deficits and household credits, SBC suggests an ARDL $(2,1)$ procedure for the models with and without a linear trend. ${ }^{14}$

The coefficients of the long-run relationships and the

14 To save some space, the underlying ARDL models for the variables are not presented here. error-correction representations of the ARDL models are given in Table 4 and Table 5 respectively.

The long-run relationships indicate positive association between variables as seen in Table 4. According to the results reported in Table 5, $E C T_{t-1}$ coefficients are negative and statistically significant in all cases, implying causality between the variables of interest in the long run. The significance of $E C T_{t-1}$ implies that if the system is exposed to a shock, it will converge to the long-run equilibrium. The error-correction terms above indicate moderate speeds of convergence to the equilibrium in case of a shock, i.e. the long-run equilibrium is attained after 5 or 6 quarters. 
Table 6. Granger Causality Tests

\begin{tabular}{|c|c|c|c|c|c|c|c|c|}
\hline & \multicolumn{4}{|c|}{ Short-run Causality } & \multirow{2}{*}{\multicolumn{2}{|c|}{$\begin{array}{c}\text { Long-run Causality } \\
\text { ECT }_{t-1}\end{array}$}} & \multirow{2}{*}{\multicolumn{2}{|c|}{$\begin{array}{c}\text { Strong Causality } \\
\text { Short- and Long-run }\end{array}$}} \\
\hline & \multicolumn{2}{|c|}{$\Delta c r e d i t$} & \multicolumn{2}{|c|}{ Shhold } & & & & \\
\hline & Constant & $\begin{array}{l}\text { Constant } \\
\& \text { Trend }\end{array}$ & Constant & $\begin{array}{l}\text { Constant } \\
\& \text { Trend }\end{array}$ & Constant & $\begin{array}{l}\text { Constant } \\
\& \text { Trend }\end{array}$ & Constant & $\begin{array}{l}\text { Constant } \\
\& \text { Trend }\end{array}$ \\
\hline \multicolumn{9}{|l|}{ Model I } \\
\hline$\triangle C A D$ & $\begin{array}{l}17.7599 \\
{[0.000]}\end{array}$ & $\begin{array}{l}15.3439 \\
{[0.000]}\end{array}$ & - & - & $\begin{array}{l}-4.9673 \\
{[0.000]}\end{array}$ & $\begin{array}{l}-5.9975 \\
{[0.000]}\end{array}$ & $\begin{array}{r}38.9097 \\
{[0.000]} \\
\end{array}$ & $\begin{array}{l}48.0028 \\
{[0.000]}\end{array}$ \\
\hline \multicolumn{9}{|l|}{ Model II } \\
\hline$\triangle T R A$ & - & - & $\begin{array}{c}27.5316 \\
{[0.000]} \\
\end{array}$ & $\begin{array}{c}29.4280 \\
{[0.000]} \\
\end{array}$ & $\begin{array}{l}-6.8454 \\
{[0.000]}\end{array}$ & $\begin{array}{l}-6.8957 \\
{[0.000]}\end{array}$ & $\begin{array}{l}86.9110 \\
{[0.000]}\end{array}$ & $\begin{array}{l}87.1399 \\
{[0.000]}\end{array}$ \\
\hline
\end{tabular}

Wald-statistics are given for short-run and strong causality, whereas t-statistics of the lagged error-correction terms are reported for the long-run causality. Numbers in parenthesis are $p$-values.

Before proceeding to the causality tests, the cumulative sum (CUSUM) and cumulative sum of squares (CUSUMSQ) tests are implemented to investigate the stability of the short-run and long-run coefficients. With and without trends for each case, Fig.A1 and A2 in the Appendix present the plot of CUSUM and CUSUMSQ test statistics for Model I and Model II respectively.

The test statistics for Model I fall inside the critical bounds of 5 per cent significance, indicating stability of the parameters over the period of analysis for the current account deficits and private credits relationship (Fig.A1.a-d). Results of the CUSUM and CUSUMSQ tests for trade deficits and household credits model without a linear trend indicate stability in the coefficients as the statistics are also confined within the critical bounds (Fig.A2.a-b). However, the CUSUM and CUSUMSQ tests for Model II with trend seem to be inconclusive, as the CUSUM test statistics imply instability in parameters, whereas the CUSUMSQ test supports stability (Fig.A2.c-d).

Finally, the Granger causality implications from total credits towards current account deficits, and from household credits towards trade deficits are investigated by employing relevant tests in the above ECM frameworks. With the existence of long-run relationship, the causality inferences can be made both in the short and long run. The results are presented in Table 6.

The short-run Granger causality is investigated by imposing Wald restrictions on the short-run coefficients in the models, whereas $t$-statistics of the lagged error-correction terms refer to the long-run causality. The joint significance of short-run coefficients and error-correction term indicates strong causality. As seen in Table 6, all terms have significance at 1 per cent levels. The short-run coefficients carry positive signs, and the signs of the lagged error-correction terms are negative, i.e. suggesting convergence towards equilibrium in both of the models. The empirical findings in the table suggest Granger causality running from credit variables, i.e. household credits and total credits, to external deficits, i.e. trade deficits and current account deficits, in the short and long run at 1 per cent significance level. Furthermore, credit variables Granger-cause external deficits in the strong sense as revealed by the results.
The Turkish economy experienced relatively high growth rates in the 2000s prior to the global crisis. This growth process was accompanied by large capital inflows and domestic credit expansion, which was, in turn, fed by these inflows. The private sector's domestic credit expansion has been associated with consumption expenditures, as well as housing and productive investments, as indicated by the data on household and corporate sector credits. The increased demand for imported consumption goods and intermediate goods has led to increases in imports component of the trade balance, hence adding to the current account deficits. ${ }^{15}$ Furthermore, due to the increasing dependency of domestic production (mainly manufacturing) on imported components, a rise in the level of production in general, and more specifically in exports, has been accompanied by increases in imports. Overall, the empirical findings of the study provide some evidence for the alleged relationship between domestic credit growth and external balances in the Turkish economy in the Granger sense over the period of analysis.

\section{Conclusions}

While large current account deficits have been one of the critical issues, high credit growth rates in the past few years have also led to distress about financial and macroeconomic stability in the Turkish economy. Among others, one of the foremost concerns regarding the high credit growth in Turkey has stemmed from its alleged relationship with current account deficits. Accordingly, the CBRT designed and implemented a new policy framework effective from the end of 2010 to bring credit growth down to more 'sustainable' levels, and hence, to contribute to the reduction in current account deficits. Although credit growth has lost its pace during the past couple of years, it still seems to have a key role in the central bank policy.

This study aims to investigate the relationship between domestic credit growth and external balances of the Turkish economy. To this end, the study employs the ARDL bounds

15 Reasonably low exchange rates during most of the period made imports more attractive, further contributing to current account deficits. 
testing methodology and search for causal inferences from private credits towards external deficits. The ARDL-ECM framework allows us to consider causality implications both in the long and short run.

The empirical findings of the paper indicate causality from credit variable(s) towards external deficits a la Granger. The Turkish current account and trade deficits seem to respond total private credits and household credits, respectively. These findings suggest that the changes in credit levels may have an impact on current account and trade deficits, and hence, attempts to control credit expansion may help to curb current account deficits. However, before imposing any kind of restrictions, other possible determinants of current account balances should also be considered. Moreover, taking measures to limit overall credit growth in order to curb external deficits may have implications for the economy in general, mainly by contracting economic growth. Therefore, imposing a selective credit policy regarding different credit categories seems to be more appropriate as a complementary policy tool.

\section{Appendix}

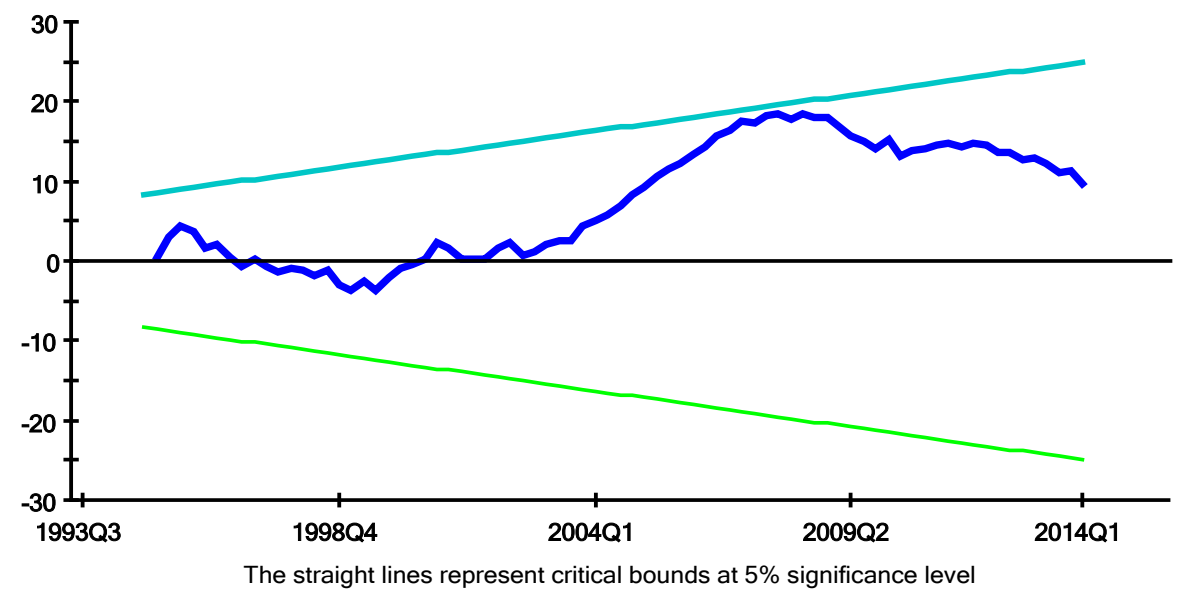

(a) Plot of Cumulative Sum of Recursive Residuals - without trend

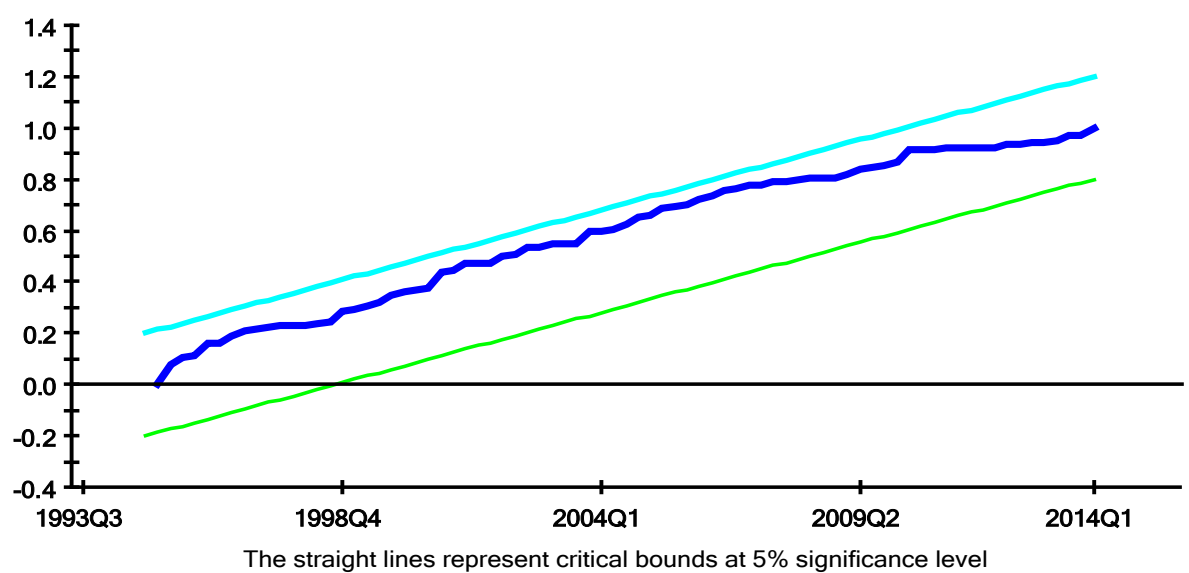

(b) Plot of cumulative sum of squares of recursive residuals - without trend 


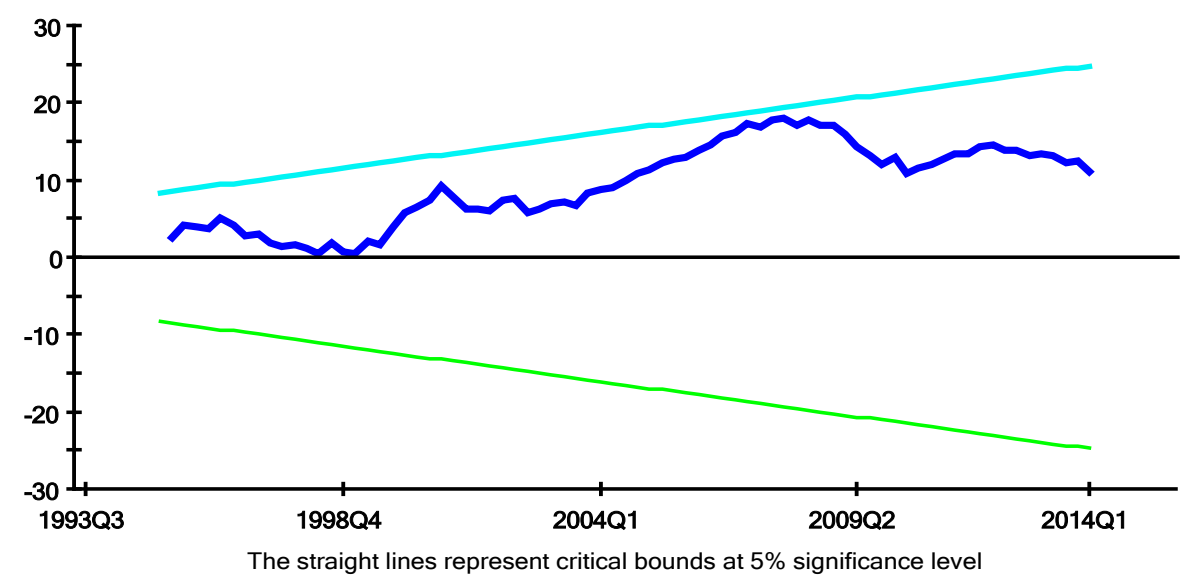

(c) Plot of cumulative sum of recursive residuals - with trend

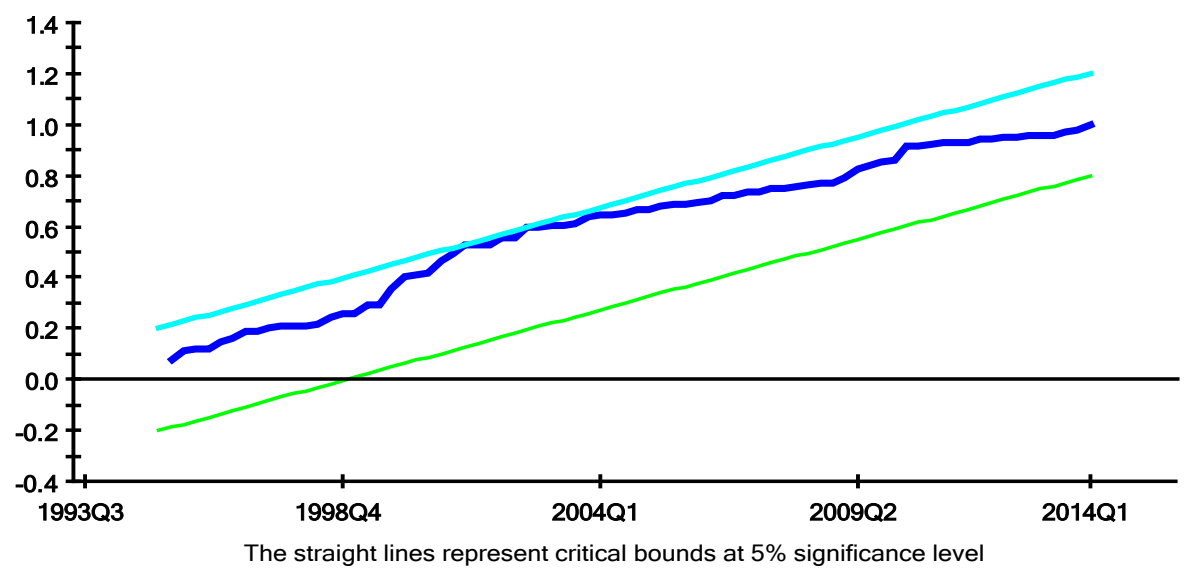

(d) Plot of cumulative sum of squares of recursive residuals - with trend

Figure A1. (a-d) CUSUM and CUSUMSQ Tests for Model I : Current Account Deficits and Credits

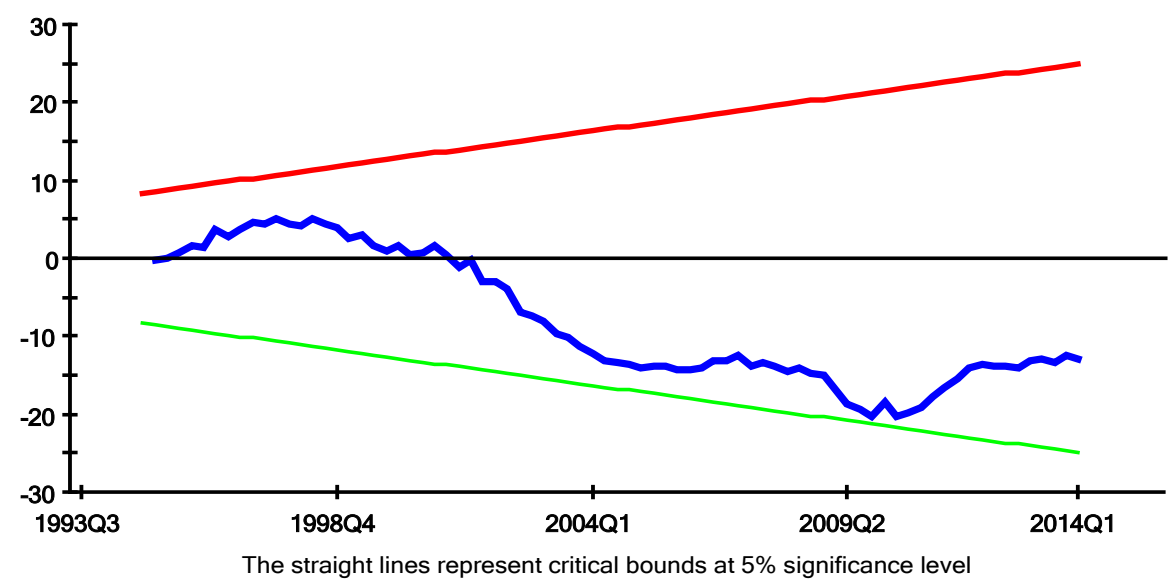

(a) Plot of cumulative sum of recursive residuals - without trend 


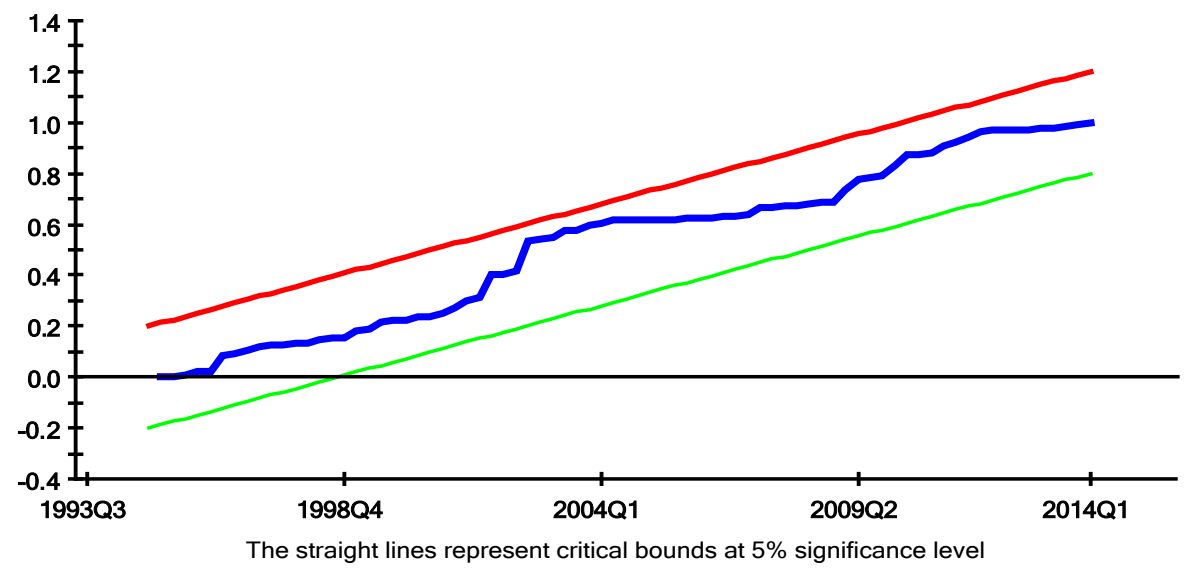

(b) Plot of cumulative sum of squares of recursive residuals - without trend

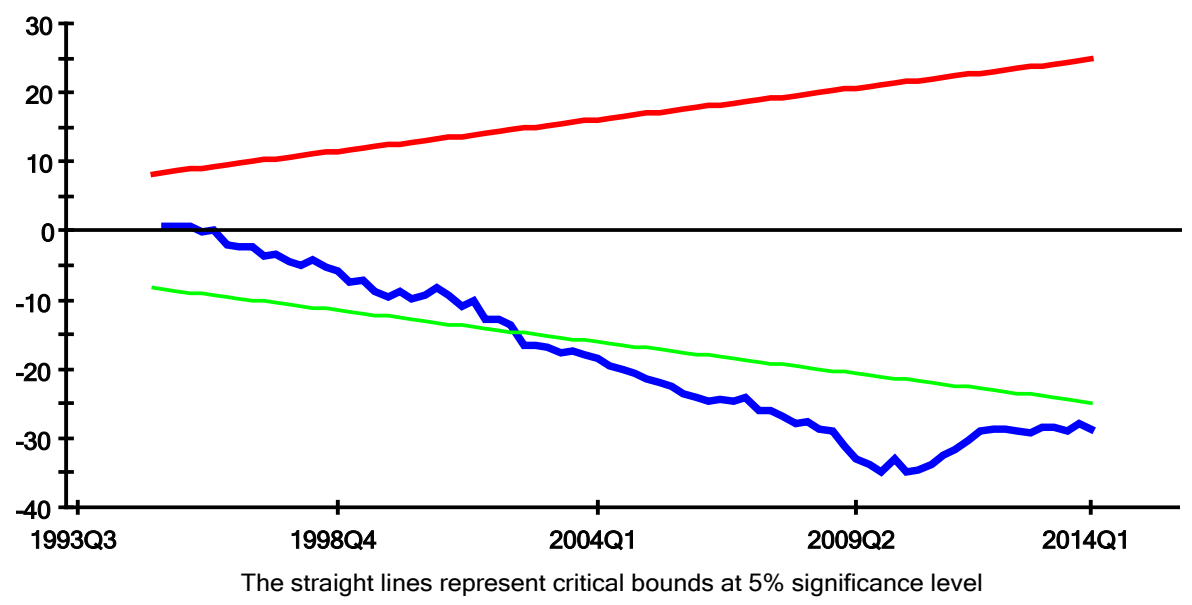

(c) Plot of cumulative sum of recursive residuals - with trend

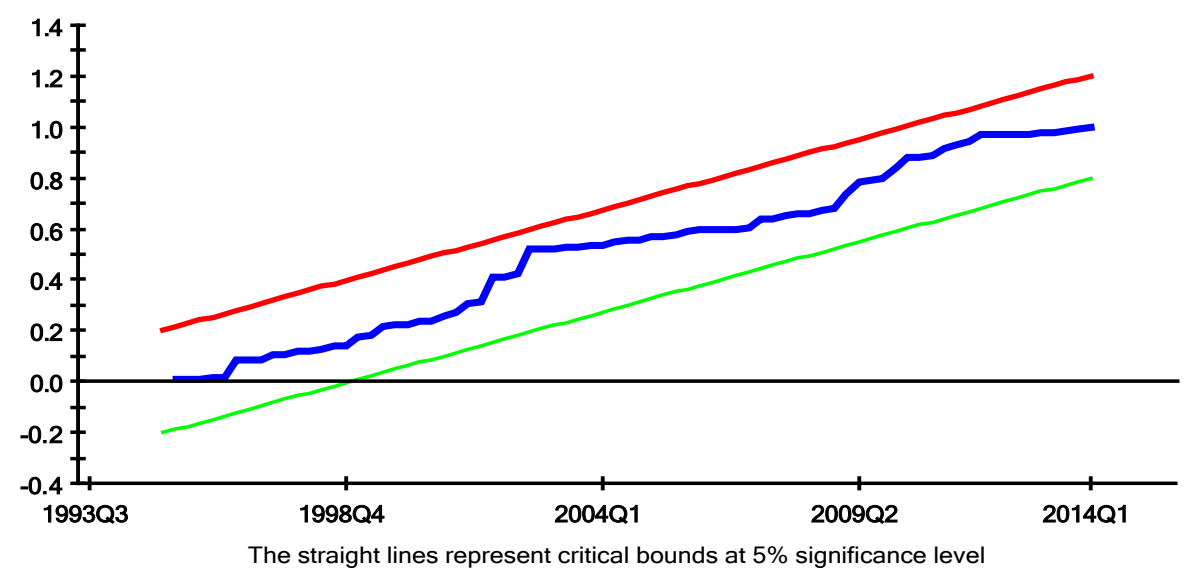

(d) Plot of cumulative sum of squares of recursive residuals - with trend

Figure A2 (a-d). CUSUM and CUSUMSQ Tests for Model II : Trade Deficits and Household Credits 


\section{REFERENCES}

[1] Z. Yukseler. Türkiye'nin Karşılaştırmalı Cari İşlemler Dengesi ve Rekabet Gücü Performans1: 1997-2010 Dönemi (in Turkish), CBRT Report, Ankara, 2011.

[2] E. Basci. Reserve Requirements and Other Macroprudential Policies: Experiences In Emerging Economies, Speech, 8 October 2012, Istanbul.

[3] H. Kara. Monetary Policy in Turkey After the Global Crisis, Working Papers No. 1217, Research and Monetary Policy Department, Central Bank of the Republic of Turkey, 2012.

[4] H. Kara, H. Kucuk, T. Tiryaki, C. Yuksel. In Search of a Reasonable Credit Growth Rate for Turkey, CBRT Research Notes in Economics, January 2013.

[5] E. Basci, H. Kara. Financial Stability and Monetary Policy (in Turkish), CBRT Working Paper, No.11/08, 2011.

[6] G. Bitzis, J.M. Paleologos, C. Papazoglou. The Determinants of the Greek Current Account Deficit: The EMU Experience, Journal of International and Global Economic Studies, 1(1), 105-122, 2008.

[7] S.N. Brissimis, G. Hondroyiannis, C. Papazoglou, N.T. Tsaveas, M.A. Vasardani. Current Account Determinants and External Sustainability in Periods of Structural Change, ECB Working Paper Series, No.1243, 2010.

[8] R. Atoyan, J. Manning, J. Rahman. Rebalancing: Evidence from Current Account Adjustment in Europe IMF Working Paper, No: 13/74, 2013.

[9] IMF. External Balance Assessment (EBA): Technical Background, 2013. Available online at: http://www.imf.org/external/np/res/eba/pdf/080913.pdf.

[10] M.F. Ekinci, F.P. Erdem, Z. Kilinc, Credit Growth, Current Account and Financial Depth, CBRT Working Paper, No.14/21, 2014.

[11] M.H. Pesaran, Y. Shin. An Autoregressive Distributed Lag Modelling Approach to Cointegration Analysis in S.Storm, A. Holly, and P. Diamond (eds.), Centennial Volume of Ragnar Frisch. Cambridge, New York: Cambridge University Press, 1999.

[12] M.H. Pesaran, Y. Shin, R.J. Smith. Bounds testing approaches to the analysis of level relationships. Journal of Applied Econometrics, 16, 289-326, 2001.

[13] M.H. Pesaran, Y. Shin. An Autoregressive Distributed Lag Modelling Approach to Cointegration Analysis, revised version of a paper presented at the Symposium at the Centennial of Ragnar Frisch, The Norwegian Academy of Science and Letters, Oslo, March 3-5, 1995.

[14] M.H. Pesaran, Y. Shin, R.J. Smith. Testing for the Existing of a Long-Run Relationship, DAE Working Papers, No. 9622, Department of Applied Economics, University of Cambridge, 1996.

[15] R.F. Engle, C.W.J. Granger. Cointegration and Error Correction: Representation, Estimation, and Testing, Econometrica, 55, 251-276, 1987.
[16] S. Johansen. Statistical Analysis of Cointegrating Factors, Journal of Economic Dynamics and Control, 12, 231-254, 1988.

[17] S. Johansen, K. Juselius. Maximum Likelihood Estimation and Inference on Cointegration- with Applications to the Demand for Money. Oxford Bulletin of Economics and Statistics, 52(2), 169-210, 1990.

[18] R.I. McKinnon, P.Huw. Credible Economic Liberalizations and Overborrowing, American Economic Review, 87(2), 189-93, 1997.

[19] G.L. Kaminsky, C.M. Reinhart. The twin crises: the causes of banking and balance of payments problems, American Economic Review, 89(3), 473-500, 1999.

[20] P.O. Gourinchas, R. Valdés, O. Landerretche. Lending booms: Latin America and the world, NBER Working Paper, No.8249, National Bureau of Economic Research, 2011.

[21] O. Jordà, M. Schularick, A.M. Taylor. Financial Crises, Credit Booms, and External Imbalances: 140 Years of Lessons, IMF Economic Review, 59(2), 340-378, 2011.

[22] M. Schularick, A.M. Taylor. Credit Booms Gone Bust: Monetary Policy, Leverage Cycles, and Financial Crises, 1870-2008, American Economic Review, 102(2), 1029-1061, 2012.

[23] G. Dell'Ariccia, D. Igan, L. Laeven, H. Tong (with B. Bakker ve J. Vandenbussche). Policies for Macrofinancial Stability: How to Deal with Credit Booms, IMF Staff Discussion Note, SDN/12/06, 2012.

[24] M. Bordo, O. Jeanne. Boom-Busts in asset prices, economic instability and monetary policy, NBER Working Paper, No.8966, National Bureau of Economic Research, Cambridge, 2002.

[25] C. Borio, P. Lowe. Asset Prices, Financial and Monetary Stability: Exploring the Nexus, BIS Working Paper, No.114, Bank for International Settlements, Basel, 2002.

[26] A. Tornell, F. Westermann. Boom-Bust Cycles in Middle-Income Countries: Facts and Explanation, IMF Staff Papers, 49, 111-55, 2002.

[27] IMF. Are credit booms in emerging markets a concern?, World Economic Outlook, April, 2004.

[28] V. Coudert, C. Pouvelle. Assessing the Sustainability of Credit Growth: The Case of Central and Eastern European Countries, European Journal of Comparative Economics, 7(1), 87-120, 2010.

[29] S. Barisitz. The Transformation of the Romanian Financial and Banking Sector, Financial Stability Report, National Bank of Romania, 88-100, 2004.

[30] B. Egert, P. Backé, T. Zumer. Credit growth in central and eastern Europe: new (over)shooting stars?, ECB WP Series, No.687, 2006.

[31] C. Enoch, I. Otker-Robe (eds). Rapid Credit Growth in Central and Eastern Europe: Endless Boom or Early Warning? New York: Palgrave Macmillan, 2007.

[32] A. Gersl, J. Seidler. Excessive Credit Growth As an Indicator of Financial (In)Stability And Its Use in Macroprudential Policy, Financial Stability Report 2010/2011, Czech National Bank. 
[33] IMF. Slowing Growth, Rising Risks, World Economic Outlook, September, 2011.

[34] H.T. Patrick. Financial Development and Economic Growth in Underdeveloped Countries, Economic Development and Cultural Change, 14(1), 174-189, 1966.

[35] N. Kiyotaki, J. Moore. Credit Cycles, Journal of Political Economy, 105, 211-248, 1997.

[36] B. Bernanke, M. Gertler, S. Gilchrist. The Financial Accelerator in and Quantitative Business Cycle Framework in Handbook of Macroeconomics, Vol. 1C, ed. by John Taylor and Michael Woodford (Amsterdam: North-Holland), 1531-1614, 1999.

[37] E. G. Mendoza, M. E. Terrones. An Anatomy of Credit Booms: Evidence from Macro Aggregates and Micro Data, Working Paper, No.14049, 2008.

[38] C. Duenwald, N. Gueorguiev, A. Schaechter. Too much of a good thing? Credit booms in Transition Economies: the cases of Bulgaria, Romania and Ukraine, IMF Working Paper, $\mathrm{WP} / 05 / 128,2005$.

[39] B.B. Bakker, A.M. Gulde. The Credit Boom in the EU New Member States: Bad Luck or Bad Policies?, IMF Working Paper, No. 10/130, 2010.

[40] O. Blanchard, G.M. Milesi-Ferretti. (Why) Should Current Account Balances Be Reduced?, IMF Staff Discussion Note, $\mathrm{SDN} / 11 / 03,2011$.

[41] A. Ghosh, U. Ramakrishnan. Current Account Deficits: Is There a Problem?, Finance and Development, March 2012.

[42] B.B. Bakker, A.M. Gulde. Searching for Stability, Finance and Development, June, 50-51, 2010.

[43] G.M. Milesi-Ferretti, A. Razin. Current account reversals and currency crises: empirical regularities, NBER Working Paper, No. 6620, NBER: Massachusetts, 1998.

[44] S. Edwards. Thirty Years of Current Account Imbalances, Current Account Reversals and Sudden Stops, NBER Working Paper, No. 10276, NBER: Massachusetts, 2004.
[45] S. Edwards. Financial Openness, Sudden Stops and Current Account Reversals, NBER Working Paper, No. 10276, NBER: Massachusetts, 2004.

[46] R. Moreno. Experiences with Current Account Deficits in Southeast Asia, Central Bank of Chile Working Papers, No.452, 2007.

[47] E. Telatar. Turkiye'de Cari Acigin Belirleyenleri ve Cari Acik-Krediler Iliskisi (in Turkish), Bankacilar Dergisi, 78, 22-34, 2011

[48] M. Binici, B. Köksal, B. Türkiye'de Aşırı Kredi Genişlemeleri, (in Turkish), CBRT, Research Notes in Economics, July 2012.

[49] J. Baek. The J-Curve and the U.S.-Canada Forest Products Trade, Journal of Forest Economics, 13(4), 245-258, 2007.

[50] P.K. Narayan. The Saving and Investment Nexus for China: Evidence From Cointegration Tests, Applied Economics, 37, 1979-1990, 2005.

[51] R.L. Brown, J. Durbin, J.M. Evans. Techniques for Testing the Constancy of Regression Relationships over Time. Journal of the Royal Statistical Society (Series B), 37(2), 149-163, 1975.

[52] D.A. Dickey, W.A. Fuller. Distribution of the Estimators for Autoregressive time series with unit root, Journal of American Statistical Association, 74, 427-431, 1979.

[53] P.C.B. Phillips, P. Perron. Testing for a unit root in time series regressions, Biometrica, 75, 335-346, 1988.

[54] G. Elliott, T.J. Rothenberg, J.H. Stock. Efficient tests for an autoregressive unit root, Econometrica, 64, 813-836, 1996.

[55] D. Kwiatkowski, P.C.B. Phillips, P. Schmidt, Y. Shin. Testing the null hypothesis of stationary against the alternative of a unit root, Journal of Econometrics, 54, 159-178, 1992.

[56] J.L. Carrion-i-Silvestre, D. Kim, P. Perron. GLS-based unit root tests with multiple structural breaks under both the null and the alternative hypotheses, Econometric Theory, 25, 1754-1792, 2009. 